REFLECTIONS:

NEUROLOGY AND THE

HUMANITIES

Section Editor

Anne W. McCammon,

MD, FAAN

\title{
Reflections for July
}

Harvey J. Blumenthal,

MD

Address correspondence and reprint requests to Dr. Harvey J. Blumenthal, 2949 E 57th Street, Tulsa, OK 74105

hblumenthal@cox.net
THE SMELL BRAIN

In song and story, composers, writers, and artists have paid tribute to eyes that can appreciate beautiful art, ears delighted by music, sensual tactile pleasures to share with our lovers; and Hemingway often wrote about delicious tastes. But the poor neglected nose begets little respect. Perhaps this is because the only function of the nose, to perceive odors, has declined in human evolutionary development.

MacDonald Critchley, in his 1986 book, The Citadel of the Senses, vividly described observations that butterflies have uncanny powers of detecting others of their species more than a mile away; and scientists have found that the salmon smolt finds and returns to its parent river by means of its sense of smell.

Still, human olfactory perception can be fascinating to contemplate. Critchley detailed how the "smell brain" has declined in humans while there has been enhancement of vision, hearing, and the dexterity of our hands: "What remains are powerful neurologic connections between smell and memory." Several years ago, in my class at Tulsa University, "Writing Your Memoirs," several classmates wrote how the fragrance of flowers intensely relates to certain childhood, or even adult, memories; and one 80-year-old man read his touching memoir, associating memories of pungent wood smoke with his boyhood Vermont home.

Cigar smoke places me in my Aunt Betty's living room on Friday nights in 1949, watching boxing bouts while Uncle Jack puffed on a Roi-Tan cigar. When I have occasion to review some anatomic point, formaldehyde still wafts faintly from my old anatomy dissection book, and I think of Tom McGovern, my lab partner of long ago. But, most of all, I sometimes smell my wife's hair, and it is 1954 , and we are 16 again. 


\title{
Neurology
}

\author{
Reflections for July \\ Harvey J. Blumenthal \\ Neurology 2011;77;192 \\ DOI 10.1212/WNL.0b013e3182242d5e
}

\section{This information is current as of July 11, 2011}

\section{Updated Information \&}

Services

Permissions \& Licensing

Reprints including high resolution figures, can be found at: http://n.neurology.org/content/77/2/192.full

Information about reproducing this article in parts (figures,tables) or in its entirety can be found online at:

http://www.neurology.org/about/about_the_journal\#permissions

Information about ordering reprints can be found online:

http://n.neurology.org/subscribers/advertise

Neurology ${ }^{\circledR}$ is the official journal of the American Academy of Neurology. Published continuously since 1951, it is now a weekly with 48 issues per year. Copyright Copyright (? 2011 by AAN Enterprises, Inc.. All rights reserved. Print ISSN: 0028-3878. Online ISSN: 1526-632X.

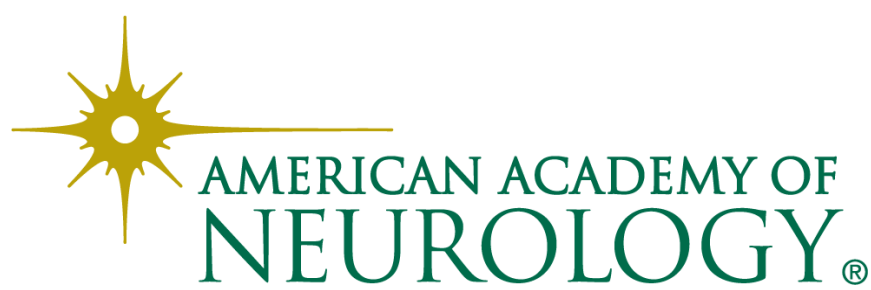

